\title{
Regional Anesthesia for Anorectal Surgeries: What is the Best Solution?
}

\author{
(1) Tahsin Şimşek, ${ }^{1}$ (1) Ayten Saraçoğlu, ${ }^{2}$ (1) Ülgen Zengin, ${ }^{2}$ \\ (1) Mehmet Yılmaz, ${ }^{3}$ (1) Kemal Tolga Saraçoğlu
}

\begin{abstract}
'Department of Anesthesiology and Reanimation, Kartal Dr. Lütfi Kırdar City Hospital, İstanbul, Turkey ${ }^{2}$ Department of Anesthesiology and Reanimation, Marmara University Pendik Training and Research Hospital, İstanbul, Turkey

${ }^{3}$ Department of Anesthesiology and Reanimation, Health Sciences

University Derince Training and

Research Hospital, Kocaeli, Turkey

Submitted: 02.02.2021

Accepted: 23.02.2021

Correspondence: Tahsin Şimşek, Kartal Dr. Lütfi Kırdar Şehir Hastanesi,

Anesteziyoloji ve Reanimasyon Kliniği, İstanbul, Turkey

E-mail: simsektahsin2017@gmail.com
\end{abstract}

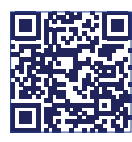

Keywords: Anorectal surgery; caudal block; saddle block.

(c) (1) (2)

This work is licensed under a Creative Commons Attribution-NonCommercial 4.0 International License.

\begin{abstract}
Objective: Different regional anesthesia techniques are used in anorectal surgeries. The ideal anesthetic method should provide adequate analgesia, patient comfort and safety, and enable early mobilization. The aim of this study was to compare the effects of caudal block and saddle block techniques on post-operative analgesic consumption, number of patients requiring analgesic agent, and initial analgesic requirement.
\end{abstract}

Methods: The current study included 7I patients undergoing elective anorectal surgery. In the saddle block group, we inserted $25 \mathrm{G}$ Quincke spinal needle by the ultrasonography guidance into the intrathecal space at L4-L5 level and administered $7.0 \mathrm{mg}$ hyperbaric bupivacaine. In the caudal block group, we inserted $20 \mathrm{G}$ caudal needle by ultrasound guidance into the epidural space at S4-S5 level and administered $25 \mathrm{ml}$ bupivacaine at a concentration of $0.5 \%$.

Results: In group caudal, post-operative analgesic consumption and number of patients requiring analgesic agent were significantly lower than group saddle $(p<0.05)$. In group saddle, first analgesic requirement time was significantly lower than group caudal $(p<0.05)$.

Conclusion: In this study, significantly better results were obtained in group caudal regarding post-operative analgesic consumption, number of patients requiring analgesic agent, and initial analgesic requirements time. We concluded that caudal block can be more efficient for anorectal surgery in clinical practice.

\section{INTRODUCTION}

Pilonidal sinus, hemorrhoidectomy, anal fistula or fissure repair are the main types of anorectal surgery. Various surgical and anesthetic techniques have been introduced to improve analgesia level and limit the motor blockade. Both caudal block and saddle block are frequently used and the cost ratio is low. ${ }^{[1]}$ Regional anesthesia is preferred for anorectal surgeries to avoid the risks of general anesthesia. Besides, providing effective post-operative analgesia, regional techniques reduce the opioid use. Despite the apparent advantages regarding patient safety, there is a lack of direct comparison for different regional techniques. Therefore, it still remains controversial whether to perform the ideal anesthesia method for anorectal surgeries. ${ }^{[2,3]}$

Saddle block provides an acceptable hemodynamic stability and a high degree of success rate. ${ }^{[4]}$ The extension and duration of motor blockade should be followed. Caudal block is widely used both in adult and pediatric patients. [5] Inadvertent dural puncture or incidental intravascular injections are the risks during the caudal approach.

In this prospective, randomized study, we aimed to investigate the effects of caudal block and saddle block in patients undergoing anorectal surgery. The primary outcome of the study was to compare the post-operative analgesic consumption in two groups. Secondary aim was to compare the number of patients requiring analgesic agent, initial analgesic requirement time, and sensory and motor block levels.

\section{MATERIALS AND METHODS}

Following the ethics committee approval (KOU-GAEK: 2017-384) and informed patient consents, 71 patients with the American Society of Anesthesiologists (ASA) 
I-2 risk group undergoing elective anorectal surgery were included in the study. The study was registered at clinicaltrials.gov registry system with the number of NCT03498547. The study was conducted between April 2018 and October 2018 in our university hospital. The exclusion criteria consisted of patient refusal, history of allergy to local anesthetics, and contraindications for regional anesthesia. ${ }^{[6]}$

Standard monitorization was provided in the operating theater with electrocardiography, peripheral oxygen saturation, and non-invasive blood pressure measurement. Basal hemodynamic-vital parameters of patients were recorded. Patients were randomized into two treatment groups as caudal (Group C) and saddle block (Group S). The randomization was performed using the random number generator in https://www.random.org.

Saddle block was performed in a sitting position, using 25 G Quincke spinal needle with the guidance of ultrasonography (USG) (Mindray M5, China). Using the Tuffier's line as an anatomical landmark, the L4-L5 interspaces were identified. $1.4 \mathrm{ml}$ of $0.5 \%$ of hyperbaric bupivacaine $(7.0 \mathrm{mg})$ was administered. Afterward, the patient was kept in sitting position for 5 min. Caudal block was performed with traditional landmark technique. The patients were positioned in the prone, jack-knife position. A $25 \mathrm{G}$ adult caudal needle was inserted under USG guidance to reach the caudal epidural space at S5 or S4 interspaces. Twenty-five milliliters of $0.5 \%$ plain bupivacaine were injected in caudal epidural space. Once a level of sensory block has been attained at L5-SI level surgery was initiated.

Heart rate (HR), systolic, diastolic, and mean arterial pressure (MAP) values were recorded every 15 min perioperatively.

The sensory block level was assessed using loss of light touch and sharp pinprick sensation.

Using the modified Bromage scale, the level of motor block was assessed: Grade 0 = no weakness; Grade I = inability to raise extended leg; Grade 2 = inability to flex knee; and Grade 3 = inability to move lower limb. In case of insufficient or failed block, general anesthesia was used. In assessment of pain intensity, $10 \mathrm{~cm}$ visual analog scale (VAS) was used. Before surgery, patients were informed as: " 0 " represents no pain and " 10 " represents the maximum intolerable pain one can ever experience on the scale. ${ }^{[7]}$ Patients were aware that additional analgesic agents will be administered postoperatively on their demand when their VAS scores exceed 3. At the end of surgery, pain levels were evaluated at $0^{\text {th }}, 30^{\text {th }}$, and $60^{\text {th }}$ min using the VAS scale. It was planned to administer I gr paracetamol, whenever the measured VAS score was $>3$ in the early post-operative period during the first $24 \mathrm{~h}$. Time interval between bupivacaine administration and the requirement of first analgesic drug was recorded. Post-operative analgesic consumption and the number of patients requiring analgesic agent in post-operative $24 \mathrm{~h}$ were recorded. The duration of motor block was assessed every hour until the ability of the patient to move fingers.

\section{Statistical methods}

SPSS 22.0 program was used in the analysis. In the descriptive statistics of data, average, standard deviation, median, lowest, highest, frequency, and ratio values were used. Distribution of variables was measured with Kolmogorov-Smirnov test. Mann-Whitney U-test was used in the analysis of dependent quantitative data. In the analysis of independent qualitative data, Chi-square test was used and if conditions of Chi-square were not provided, Fisher's test was used. $\mathrm{P}<0.05$ was determined for statistical difference.

The sample size of the groups was determined with power analysis. To keep the study at a power level above $90 \%$ and a type I error level below 5, it is calculated that a total of 60 patients with 30 patients in each group must be included. However, considering the possible losses, the sample size of the groups was kept larger in the study.

\section{RESULTS}

Seventy-five patients were screened in this study. Two patients had coagulation disorders and two of the patients declined block procedures, all of them were removed from the study. The data of 54 males and 17 females were analyzed (Fig. I). The mean age in Group C was 34.I6 12.85

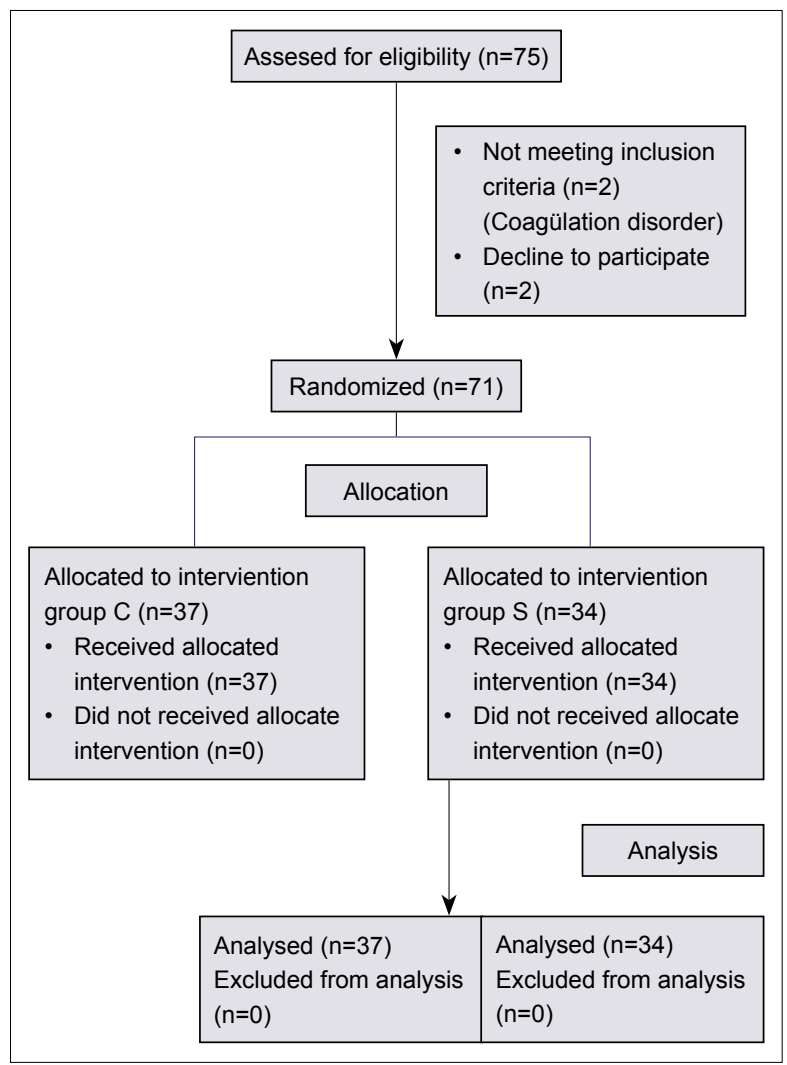

Figure 1. The flow diagram of patient progress through the randomized trial. 
Table I. The demographic data of patients

\begin{tabular}{|c|c|c|c|}
\hline & Group C, n (37) & Group S, n (34) & $\mathbf{p}$ \\
\hline \multicolumn{4}{|l|}{ Gender, n (\%) } \\
\hline Female & $9(24.3)$ & $8(23.5)$ & $0.938^{x^{2}}$ \\
\hline Male & $28(75.7)$ & $26(76.5)$ & \\
\hline \multicolumn{4}{|l|}{ ASA score, $n(\%)$} \\
\hline 1 & $23(62.2)$ & $29(85.3)$ & $0.034^{2}$ \\
\hline 2 & $14(37.8)$ & $5(14.7)$ & \\
\hline \multicolumn{4}{|l|}{ Type of surgery, n (\%) } \\
\hline Pilonidal sinus & $22(59.5)$ & $24(70.6)$ & $0.587^{2}$ \\
\hline Anal fissure-fistula & $8(21.6)$ & $6(17.6)$ & \\
\hline Hemorrhoid & $7(18.9)$ & $4(11.8)$ & \\
\hline Age (years), mean $\pm S D$ & $34.16 \pm 12.85$ & $28.88 \pm 9.13$ & $0.124^{\mathrm{m}}$ \\
\hline Duration of surgery (min), median (min-max) & $25(5-45)$ & $30(5-60)$ & $0.295^{\mathrm{m}}$ \\
\hline
\end{tabular}

and 28.88 \pm 9.13 in Group S and there was no significant difference between groups. With respect to the duration of surgery, there was also no significant difference among the groups (Table I). ASA scores were significantly higher

Table 2. Comparison of motor block, success rate, and complications

\begin{tabular}{|c|c|c|c|}
\hline & $\begin{array}{c}\text { Group C } \\
\text { n (\%) }\end{array}$ & $\begin{array}{c}\text { Group } S \\
\text { n (\%) }\end{array}$ & p \\
\hline \multicolumn{4}{|l|}{ Motor block } \\
\hline Yes & $5(13.5)$ & $33(87.1)$ & $0.001 x^{2}$ \\
\hline No & $32(86.5)$ & I (2.9) & \\
\hline \multicolumn{4}{|l|}{ Insufficient block } \\
\hline Yes & $2(5.4)$ & I (2.9) & $0.195^{x^{2}}$ \\
\hline No & $35(94.6)$ & $33(97.1)$ & \\
\hline No & $29(78.4)$ & $14(4 \mid .2)$ & \\
\hline \multicolumn{4}{|l|}{ Complications } \\
\hline No & $37(100)$ & 31 (9I.2) & $0.182^{x^{2}}$ \\
\hline Bradycardia & $0(0)$ & I (2.9) & \\
\hline Headache & $0(0)$ & $2(5.9)$ & \\
\hline
\end{tabular}

${ }^{x^{2}}$ Chi-square test (Fisher's test). in Group C than Group S (Table I, $\mathrm{P}=0.034$ ). The types of surgeries included pilonidal sinus, anal fistula, fissures, and hemorrhoidectomy. In Group C, 2 patients (5.4\%), in Group S, I patient (2.9\%) experienced insufficient block (Table 2, $p=0.195$ ). There was not any complication in caudal anesthesia group. In spinal group, I patient $(2.9 \%)$ had bradycardia and 2 (5.9\%) had headache (Table 2). Both HR and MAP were significantly lower than baseline measurements in patients under spinal anesthesia (Table 3). HR values were not different from baseline in caudal group. There was a significant decrease in MAP both at 15 th min and at the end of surgery $(p=0.016$ and 0.043 , respectively). The sensory and motor block levels following spinal anesthesia were statistically higher in patients undergoing caudal anesthesia (Tables 4 and 5). VASs of post-operative first $60 \mathrm{~min}$ were not different in groups (Table 5).

Post-operative analgesic consumption was significantly higher in Group S (Table 6, $p=0.001$ ). The number of patients requiring analgesics in the post-operative $24 \mathrm{~h}$ period was significantly lower in Group C (21.6\% and 58.8\%, respectively) (Table 6, $p=0.002$ ). Group $C$ had significantly longer time to first analgesic requirement in the post-operative period $(p<0.0001$, Table 6$)$.

Table 3. The comparison of hemodynamic parameters

\begin{tabular}{|c|c|c|c|c|c|}
\hline & $\begin{array}{c}\text { Group C } \\
\text { Mean } \pm \text { SD }\end{array}$ & $\begin{array}{c}\text { Group S } \\
\text { Mean } \pm \text { SD }\end{array}$ & $\begin{array}{l}\text { Group C change } \\
\text { from baseline (p) }\end{array}$ & $\begin{array}{l}\text { Group } S \text { change } \\
\text { from baseline (p) }\end{array}$ & $\mathbf{p}$ \\
\hline 0 min HR (beat/min) & $78.1 \pm 14.2$ & $81.1 \pm 13.2$ & & & $0.26 \mathrm{I}^{\mathrm{m}}$ \\
\hline I5 min HR (beat/min) & $78.8 \pm 14$ & $76.3 \pm 12.6$ & $0.728^{w}$ & $0.006^{w}$ & $0.569^{\mathrm{m}}$ \\
\hline 30 min HR (beat/min) & $79.8 \pm 16.7$ & $73.6 \pm 12.0$ & $0.588^{w}$ & $0.00 I^{w}$ & $0.052^{\mathrm{m}}$ \\
\hline HR at the end of surgery (beat/min) & $76.4 \pm 11.7$ & $73.7 \pm 12.4$ & $0.242^{w}$ & $0.002^{w}$ & $0.430^{\mathrm{m}}$ \\
\hline $0 \mathrm{~min} M A P(\mathrm{mmHg})$ & $100.4 \pm 16.1$ & $99.6 \pm 14.0$ & & & $0.72 \mathrm{I}^{\mathrm{m}}$ \\
\hline 15 min MAP $(\mathrm{mmHg})$ & $94.0 \pm 13.8$ & $93.7 \pm 10.9$ & $0.016^{w}$ & $0.012^{w}$ & $0.945^{\mathrm{m}}$ \\
\hline 30 min $M A P(m m H g)$ & $97.8 \pm 16.9$ & $92.5 \pm 10.6$ & $0.338^{w}$ & $0.01 I^{w}$ & $0.210^{\mathrm{m}}$ \\
\hline MAP at the end of surgery $(\mathrm{mmHg})$ & $95.3 \pm 16.6$ & $94.2 \pm 9.7$ & $0.043^{w}$ & $0.027^{w}$ & $0.804^{\mathrm{m}}$ \\
\hline
\end{tabular}

mMann-Whitney U-test, "Wilcoxon test. HR: Heart rate; MAP: Mean arterial pressure; SD: Standard deviation. 
Table 4. Patients' assessment of sensory levels

\begin{tabular}{lccc}
\hline & $\begin{array}{c}\text { Group C } \\
\mathbf{n}(\%)\end{array}$ & $\begin{array}{c}\text { Group S } \\
\mathbf{n}(\%)\end{array}$ & p \\
\hline $\begin{array}{c}\text { Before surgery } \\
\text { LI-L5 }\end{array}$ & $6(16.2)$ & $13(67.6)$ & $0.00 \mathrm{I}^{2}$ \\
SI-S4 & $31(83.8)$ & $11(33.4)$ & \\
$\begin{array}{c}\text { After surgery } \\
\text { LI-L5 }\end{array}$ & $7(18.9)$ & $26(76.5)$ & $0.00 \mathrm{I}^{2}$ \\
SI-S4 & $30(8 \mathrm{I} . \mathrm{I})$ & $8(23.5)$ & \\
$\begin{array}{c}\text { After recovery } \\
\text { LI-L5 }\end{array}$ & $4(10.8)$ & $22(64.7)$ & $0.00 \mathrm{I}^{2}$ \\
SI-S4 & $33(89.2)$ & $12(35.3)$ & \\
\hline${ }^{2}$ Chi-square test (Fisher's test). & &
\end{tabular}

\section{DISCUSSION}

This prospective randomized study compared the effects of different regional anesthesia techniques during anorectal surgery. Caudal block provided better outcome including sensory block levels without motor blockade. In the caudal group, fewer patients required analgesic agent and post-operative analgesic consumption was lower during the Ist post-operative day. Lower complication rate and earlier mobilization revealed that caudal block can be a safe method in patients undergoing anorectal surgeries.
Recently, it was revealed that spinal anesthesia did not reduce the catecholamine response despite mid-thoracic analgesia levels. ${ }^{[8]}$ Therefore, the hemodynamic variables did not change. They concluded that spinal anesthesia blocked the increase in cardiac index. In our study, both MAP and HR decreased significantly in saddle block group probably due to sympathetic blockade. However, in the caudal group, only $15 \mathrm{~min}$ and at the end of surgery, MAP decreased and the HR was stable intraoperatively. Complications of spinal anesthesia include abducens nerve paralysis, tinnitus, neurological symptoms, hemodynamic depression, and asystole. ${ }^{[9,10]}$ In our study, vasopressor support was required in spinal group due to bradycardia in one patient. Headache was observed in two patients after spinal puncture and medical treatment was planned. On the other side, no perioperative complication was recorded in caudal block group. Similar to our findings, Kiasari et al. ${ }^{\left[{ }^{11}\right]}$ observed more headache in patients undergoing spinal anesthesia than epidural patients. In adults, the failure rate of caudal epidural block may be high even in experienced hands because of using conventional blind technique. ${ }^{[2]}$ Caudal block is notably preferred for anorectal surgery. However, the success rate has been reported to be 70$80 \% .{ }^{[13,14]}$ Unlike these results, the success rate of caudal anesthesia reached to $94.6 \%$ in our study. For the saddle block group, the rate was slightly higher as $97.1 \%$. The main reason might be the use of USG. In recent studies,

Table 5. Patients' assessment of Bromage score, visual analog scale, and motor block time

\begin{tabular}{|c|c|c|c|}
\hline & $\begin{array}{c}\text { Group C }(n=37) \\
\text { Median (Min-Max) }\end{array}$ & $\begin{array}{c}\text { Group S }(n=34) \\
\text { Median (Min-Max) }\end{array}$ & $\mathbf{P}$ \\
\hline Bromage score before surgery & $0(0-3)$ & $2(0-3)$ & $<0.000 I^{m}$ \\
\hline Bromage score after surgery & $0(0-3)$ & $2(0-3)$ & $<0.000 \mathrm{I}^{\mathrm{m}}$ \\
\hline Bromage score after recovery & $0(0-3)$ & $2(0-3)$ & $<0.000 \mathrm{I}^{\mathrm{m}}$ \\
\hline Duration of motor block (min) & $170(90-360)$ & $180(40-360)$ & $0.945^{\mathrm{m}}$ \\
\hline Post-operative 0 min VAS & $0(0-3)$ & $0(0-5)$ & $0.372^{\mathrm{m}}$ \\
\hline Post-operative $30 \mathrm{~min}$ VAS & $0(0-3)$ & $0(0-5$ & $0.285^{\mathrm{m}}$ \\
\hline Post-operative $60 \mathrm{~min}$ VAS & $0(0-4)$ & $0(0-5)$ & $0.359^{m}$ \\
\hline
\end{tabular}

mann-Whitney U-test, "data analysis of patients with VAS values $>3$ (group caudal $n=8$; group saddle $n=20$ ), "data analysis of patients with motor block (group caudal $n=4$; group saddle $n=33$ ). VAS: Visual analog scale.

Table 6. Post-operative assessment

\begin{tabular}{|c|c|c|c|}
\hline & $\begin{array}{c}\text { Group C }(n=37) \\
\text { Median (Min-Max) }\end{array}$ & $\begin{array}{c}\text { Group S }(n=34) \\
\text { Median (Min-Max) }\end{array}$ & $\mathbf{P}$ \\
\hline Time to first analgesic requirement (min)* & $480(360-660)$ & $180(120-600)$ & $<0.000 \mathrm{I}^{\mathrm{m}}$ \\
\hline \multirow[t]{2}{*}{ Post-operative analgesic consumption } & $0(0-2)$ & I (0-2) & $0.000 \mathrm{I}^{\mathrm{m}}$ \\
\hline & $\begin{array}{c}\text { Group C } \\
\text { n (\%) }\end{array}$ & $\begin{array}{c}\text { Group } S \\
\text { n (\%) }\end{array}$ & \\
\hline \multicolumn{4}{|l|}{ Number of patients requested analgesic } \\
\hline Yes & $8(21.6)$ & $20(58.8)$ & $0.002^{x^{2}}$ \\
\hline No & $29(78.4)$ & 14 (4I.2) & \\
\hline
\end{tabular}

mMann-Whitney U-test, ${ }^{x}{ }^{2}$ Chi-square test (Fisher's test), "data analysis of patients with VAS values $>3$ (group caudal $n=8$; group saddle $n=20$ ). 
high success rate and low complication rate were reported with the use of ultrasonography (96.9-100\%). ${ }^{[15-18]}$ In this study, all blocks were performed using USG guidance.

The optimal anesthesia method for anal surgery is a controversial issue. Shon et al. ${ }^{[1]}$ evaluated the influence of caudal blockade, saddle blockade, and lumbar epidural blockade in patients undergoing anorectal surgery. They have found out the lumbar epidural block to be a better choice than the caudal block in cases where saddle block cannot be applied. In a study conducted by Suchiya et al., ${ }^{[19]}$ it was stated that caudal blockade with the guidance of ultrasonography can be effectively used in post-operative analgesia for urinary catheter originating pain. Yapanoglu et al. ${ }^{[20]}$ observed that patients undergoing prostate trucut needle biopsy with caudal blockade, achieved adequate post-operative analgesia and early mobilization. Sacral dermatomes consisting of SI-S4 spinal nerve roots have to be successfully blocked for a better surgical anesthesia of the anorectal surgery. In our study, it was revealed that the preferred sensorial block levels for the anorectal surgeries, consisting sacral dermatomes, achieved better results with caudal block than saddle block. In addition, we observed lower Bromage scores with caudal block indicating that early mobilization was possible in these patients. Similar benefits were reported for caudal block previously. Wong et al. ${ }^{[2]]}$ found that the caudal block produced early recovery of motor blockade with minimal hemodynamic changes. By this way, fast-track caudal anesthesia is related with short-term post-operative surveillance.

Akyıldız et al. ${ }^{[5]}$ compared the outcomes of caudal block, spinal anesthesia, and local anesthesia in pilonidal sinus surgery. They have found out that caudal block was more advantageous regarding their duration of hospital stay, post-operative VAS scores, and first analgesic requirement. In our study, caudal block and saddle block VAS scores at early post-operative period were not significantly different. In both patient groups, there was no early post-operative pain due to successful block. When the groups were compared in terms of time of first analgesic requirement, the duration was significantly longer in caudal group than spinal group. In addition, post-operative $24 \mathrm{~h}$ analgesic consumption was significantly lower in the caudal block group. Considering all these results, caudal block was more effective than saddle block in terms of post-operative pain control. In our study, the time to first analgesic requirement was significantly shorter in spinal anesthesia patients. Besides, the need for post-operative analgesia was higher in this group. These results indicate that spinal anesthesia provides a dense block, however in the post-operative period, the level of sensorial and motor block may not decrease the rate of analgesic requirement.

\section{CONCLUSION}

We observed that caudal block had better outcome when compared with saddle block, by providing earlier mobilization without motor blockade. Post-operative analge- sic consumption was significantly lower during the first post-operative $24 \mathrm{~h}$. In conclusion, caudal block was found more effective and safe in patients undergoing anorectal surgery.

\section{Limitations}

The major limitation of this study was the small sample size. We analyzed the data of 7I patients. This study is limited to early post-operative ( $24 \mathrm{~h})$ findings. Further fully powered studies are needed to confirm these results.

\section{Ethics Committee Approval}

This study approved by the Kocaeli University Clinical Research Ethics Committee (Date: I2.12.2017, Decision No: 2017-384).

Informed Consent

Prospective study.

Peer-review

Internally peer-reviewed.

Authorship Contributions

Concept: T.Ş., A.S., Ü.Z.; Design: T.Ş., A.S., Ü.Z., M.Y., K.T.S.; Supervision: T.Ş., A.S., Ü.Z., M.Y., K.T.S.; Materials: T.Ş., A.S., Ü.Z., M.Y.; Analysis: T.Ş., A.S.; Literature search: T.Ş.; Writing: T.Ş.; Critical revision: K.T.S.

Conflict of Interest

None declared.

\section{REFERENCES}

1. Shon YJ, Huh J, Kang SS, Bae SK, Kang RA, Kim DK. Comparison of saddle, lumbar epidural and caudal blocks on anal sphincter tone. J Int Med Res 2016;44:1061-71.

2. Liu SS, McDonald SB. Current issues in spinal anesthesia. Anesthesiology 2001;94:888-906.

3. Urmey WF. Spinal anaesthesia for outpatient surgery. Best Pract Res Clin Anaesthesiol 2003;17:335-46.

4. Zhang Y, Bao Y, Li L, Shi D. The effect of different doses of chloroprocaine on saddle anesthesia in perianal surgery. Acta Cir Bras. 2014;29:66-70.

5. Akyıldız HY, Çatal B, Aslan M, Yiğit G, Biri I, Gündüz M, et al. Can we use caudal anesthesia in pilonidal sinus surgery. Turk J Colorectal Dis $2008 ; 18: 128-32$.

6. Kleinman W, Mikhail M. Spinal, epidural, and caudal blocks. In: MorganGE, Murray M, editors. Clinical Anesthesiology. 4th ed. New York: Lange Medical Books; 2006.

7. Subaşı D, Ekinci O, Kuplay Y, Müftüoğlu T, Terzioğlu B. Comparison of intrathecal hyperbaric bupivacaine and levobupivacaine with fentanyl for caesarean section. Göztepe Med J 2012;27:22-9.

8. Stevens RA, Beardsley D, White JL, Kao TC, Gantt R Holman S. Does spinal anesthesia result ina more complete sympathetic block than that from epidural anesthesia? Anesthesiology 1995;82:877-83.

9. Saracoglu A, Saracoglu KT, Cakir M, Cakir Z. Abducens nerve paralysis following spinal anesthesia. Turk J Anesth Reanim. 2013;41:24-6.

10. Alegbeleye BJ. Sudden cardiac arrest under spinal anesthesia in a mission hospital: A case report and review of the literature. J Med Case Rep 2018;12:144.

11. Kiasari AZ, Babaei A, Alipour A, Motevalli S, Baradari AG. Comparison of hemodynamic changes in unilateral spinal anesthesia 
versus epidural anesthesia below the T10 sensory level in unilateral surgeries: A double blind randomized clinical trial. Med Arch 2017;71:274-9.

12. Kao SC, Lin CS. Caudal epidural block: An updated review of anatomy and techniques. Biomed Res Int 2017;2017:9217145.

13. Price C, Rogers P, Prosser A, Arden NK. Comparison of the caudal and lumbar approaches to the epidural space. Annals Rheum Dis 2000;59:879-82.

14. Stitz M, Sommer H. Accuracy of blind versus fluoroscopically guided caudal epidural injection. Spine 1999;24:1371-6.

15. Klocke R, Jenkinson T, Glew D. Sonographically guided caudal epidural steroid injections. J Ultrasound Med 2003;22:1229-32.

16. Nikooseresht M, Hashemi M, Mohajerani SA, Shahandeh F, Agah M. Ultrasound as a screening tool for performing caudal epidural injections. Iran J Radiol 2014;11:e13262.

17. Chen CP, Tang SF, Hsu TC, Tsai WC, Liu HP, Chen MJ, et al. Ultra- sound guidance in caudal epidural needle placement. Anesthesiology. 2004;101:181-4.

18. Yoon JS, Sim KH, Kim SJ, Kim WS, Koh SB, Kim BJ. The feasibility of color doppler ultrasonography for caudal epidural steroid injection. Pain. 2005;118:210-4.

19. Suchiya M, Kyoh Y, Mizutani K, Yamashita J, Hamada T. Ultrasound-guided single shot caudal block anesthesia reduces postoperative urinary catheter-induced discomfort. Minerva Anestesiol. 2013;79:1381-8.

20. Yapanoglu T, Erdem AF, Cesur M, Aksoy Y, Ozbey I, Polat Ö. Efficacy and safety of caudal anaesthesia performed with $0.1 \%$ bupivacaine in transrectal ultrasonography-guided prostate biopsy. Turk J Urol 2006;32:411-5.

21. Wong SY, Li JY, Chen C, Tseng CH, Liou SC, Tsai SC, et al. Caudal epidural block for minor gynecologic procedures in outpatient surgery. Chang Gung Med J 2004;27:116-21.

\section{Anorektal Cerrahiler için Rejyonel Anestezi: En İyi Çözüm Nedir?}

Amaç: Anorektal bölge ameliyatlarında farklı bölgesel anestezi teknikleri kullanılmaktadır. İdeal anestezi yöntemi yeterli analjezi sağlamalı, hasta konforu ve güvenliğini artırmalı, erken mobilizasyona imkan vermelidir. Bu çalışmanın amacı, kaudal blok ve saddle blok tekniklerinin ameliyat sonrası analjezik tüketimi, analjezik ajan ihtiyacı olan hasta sayısı ve başlangıç analjezik gereksinim zamanı üzerine olan etkilerini karşılaştırmaktır.

Gereç ve Yöntem: Çalışmaya elektif anorektal cerrahi geçiren 7I hasta alındı. Saddle blok grubunda; ultrasonografi eşliğinde, L4-L5 seviyesinde intratekal boşluğa, $25 \mathrm{G}$ Quincke spinal iğne ile $7.0 \mathrm{mg}$ hiperbarik bupivakain uygulandı. Kaudal blok grubunda; ultrasonografi eşliğinde, S4-S5 seviyesinde epidural boşluğa, $20 \mathrm{G}$ kaudal iğne ile \%0.5 konsantrasyonda $25 \mathrm{ml}$ bupivakain uygulandı.

Bulgular: Grup kaudal'de; ameliyat sonrası analjezik tüketimi ve analjezik ajan ihtiyacı olan hasta sayısı, grup saddle'a göre anlamlı olarak düşüktü $(p<0.05)$. Grup saddle'da ilk analjezik gereksinim zamanı grup kaudal'e göre anlamlı olarak daha düşüktü $(p<0.05)$.

Sonuç: Bu çalışmada, grup kaudalde ameliyat sonrası analjezik tüketimi, analjezik ajan ihtiyacı olan hasta sayısı, başlangıç analjezik gereksinim zamanı açısından grup saddle’a göre anlamlı derecede daha iyi sonuçlar elde edildi. Kaudal bloğun klinik pratikte anorektal cerrahi için daha etkili olabileceği sonucuna varıldı.

Anahtar Sözcükler: Anorektal cerrahi; kaudal blok; saddle blok. 